\title{
A Study on the Optical Characteristics According to the Lacquer Drying Conditions for the Conservation of Lacquerwares $^{1}$ (MPR)
}

\author{
In Sun Hwang ${ }^{2} \cdot$ Jung Hae Park ${ }^{2}$ Soo-Chul Kim (i) ${ }^{3, \dagger}$
}

\begin{abstract}
In conservation treatment lacquer has been used variously as a restoration material. However, dealing with Lacquer is very difficult as it dried in high humidity that can be harmful to the base materials. Also being natural varnish, dried lacquer layer is very different from the drying condition and the quality of the lacquer. These make difficult to predict the result of drying lacquer. In this study, using the humidity control machine, firstly, the main contents of the two different type of lacquer was experimented. And these lacquers was cured in various conditions. The duration time was checked until totally hardened. After that, obtained lacquer layers was analyzed to understand optical properties. Therefore, this study made a result about the relationship between characteristics of lacquer layer and the hardening condition. As a result, duration time of the Korean lacquer drying which has average $13.4 \%$ more urushiol than the Chinese lacquer is recorded a twice or triple decrease over it of the Chinese one. And, in all types of lacquer, the higher humidity makes the faster a pace of lacquer dried. In same lacquer, the shorter the duration time of drying lacquer is much darker and glossier. However, gloss deteriorated in saturated humidity. In humidity lower than RH 70\%, lacquer is not hardened in 336 hours. When the layer totally cured through long period more than 30 days, the drying lacquer is appeared high brightness and almost transparent. Thus, in lower than $\mathrm{RH} 70 \%$, it is hard to obtain durable layer.
\end{abstract}

Keywords: lacquer, restoration material, lacquerware, paint layer, conservation treatment

\section{INTRODUCTION}

Principles of conservation and restoration of cultural heritage state that lacquerware conservation should have to use original materials in traditional way. Therefore, the materials for restoration are determined as per the structural characteristics and damage type, and the actually damaged portions are being repaired and restored according to researches (Jang, 2016). Use of lacquer is required for lacquerware conservation, but the drying conditions of lacquer are extremely strict to result in difficulty in applying it to lacquerware conservation. High temperature and high humidity are known as the best hardening conditions for lacquer. Toishi and Kenjo (1970) explained that lacquer is dried in the relative humidity of $80-85 \%$ at $0-30{ }^{\circ} \mathrm{C}$, while

${ }^{1}$ Date Received July 30, 2018, Date Accepted September 12, 2018

2 Department of Heritage Conservation And Restoration, Graduate School of Cultural Heritage, Korea National University of Cultural Heritage, Buyeo 33115, Republic of Korea

${ }^{3}$ Department of Conservation Science, University of Science and Technology, Korea National University of Cultural Heritage, Buyeo, 33115, Republic of Korea

† Corresponding author: Soo-Chul Kim (e-mail: oldforest@nuch.ac.kr, ORCID: 0000-0002-3508-8386) 
Son (2006) proposed relative humidity of $60-80 \%$ at $20-28^{\circ} \mathrm{C}$ as the hardening conditions for lacquer.

Lacquer hardens and dries in two stages in the hardening conditions. As an oxidase included in lacquer, laccase acts as a catalyst in steam to oxidize urushiol, and lacquer dries through polymerization and the lacquer film is formed through continual automatic oxidization of urushiol and oxygen (Kenjo, 1986; Kim and Lee, 2002). Oxygen is essential for this hardening process, and the urushiol functional group plays a significant role (Choi and Kim, 2018).

Although the hardening conditions and mechanism have been studied, they are not easily applicable to lacquerware conservation. First, the compositions and contents of lacquer vary according to its place of origin and extraction period, and its drying characteristics and conditions vary too much to acquire certain results. Also, as it is difficult to maintain certain temperature and humidity in the lacquer drying rack (lacquer field) used by conventional craftsmen, the accurate characteristics of lacquer films cannot be identified. Therefore, it is important to know the characteristics of lacquer being used for conservation and set the drying conditions as per the desirable features of lacquer film. However, there have been little detailed studies on various characteristics of lacquer films according to the composition and drying conditions.

Therefore, this study designs a 'humidity control machine' that offers constant temperature and humidity, and exposes the two frequently used types of lacquer to their drying conditions to analyze their drying speed and optical characteristics of lacquer films depending on the contents of the major components and predict the results of lacquer paint films. This study also proposes how to appropriately handle lacquer, the natural material which has various compositions to make durable layer.

\section{MATERIALS and METHODS}

\subsection{Wood}

From the past, materials of Korean traditional furniture included pine, fir, blacked persimmon, and palmate maple, among which pines were used most frequently (Kim and Park, 2005). Therefore, this study selected Korean pine (Pinus spp.) as specimens, which was cut into the length of $7 \mathrm{~cm}$, width of $22 \mathrm{~cm}$, and thickness of $0.7 \mathrm{~cm}$ and dried in a moisture content of $13 \%$ or less. Also, its surface was ground to make it even.

\subsection{Lacquer}

Slightly varying by case, natural lacquer is in an emulsion state as a compound of pyrocatechol (derivative from phenol, 60-65\%), moisture (20-25\%), polysaccharide (consisting gum, 5 7\%), glycoprotein (consisting nitrogen substance, 2 5\%) and laccase (oxidase, 1\%) (Cho, 2000; Kim, 2007). The types of pyrocatechol vary by tree species and climate, and the catechol of lacquer from rhus verniciflua stokes growing in Northeast Asia is urushiol (Anzai, Lu, Phuc, Miyakoshi, 2014). Also, although lacquer is extracted from same area, its composition varies according to the place of origin and extraction period.

Therefore, to compare and examine two types of lacquer with different compositions, two types of lacquer were selected for conservation, and their impurities were eliminated to use them as filtered natural lacquer. Korean lacquer from Wonju, Gangwon-do, and Chinese lacquer were used to make the specimens.

The natural lacquer of the two types were heated to remove moisture, and acetone was added to separate urushiol, and then their content proportions were analyzed (Song and Han, 2001). Moisture and urushiol were separated from these two lacquers and the contents 
Table. 1. Contents of lacquer (rate of amount except water)

\begin{tabular}{ccccc}
\hline Type of lacquer & Time & Water & Urushiol & Etc \\
\hline \hline \multirow{2}{*}{ Korean } & 1 st & 27.3 & $60.8(83.6)$ & $11.9(16.4)$ \\
& 2nd & 27.8 & $62.0(85.8)$ & $10.2(14.2)$ \\
\hline \multirow{2}{*}{ Chinese } & 1 st & 24.6 & $51.8(68.8)$ & $23.6(31.2)$ \\
& 2nd & 24.1 & $56.0(73.8)$ & $19.9(26.2)$ \\
\hline
\end{tabular}

were measured two times. The result showed average $13.4 \%$ higher content of urushiol in Korean lacquer than Chinese one (Table 1).

\subsection{Specimens}

This test was conducted through initial coating (Chochil), middle coating(Jungchil), and upper coating (Sangchil) as per the production process of lacquerware. Here, no other purification process was done on the lacquer other than impurity removal through fine filter net. Initial coating refers to applying watery lacquer to the base wood (specimen) to be absorbed on the wood in the first place to prevent moisture absorption of background wood and enhance the adhesion of next coating. Middle and upper coatings with a higher concentration of watery paint form a lacquer film of lacquer and determine its characteristics.

Half of a specimen's surface was applied with Chinese lacquer, and the other half was applied with Korean lacquer. The preliminary test showed that the specimens with 1:2 concentration ratio between lacquer and turpentine oil (diluting agent) for initial coating and 1:1 for middle and upper coating were the most suitable to observe the drying speed and paint film formations. As initial coating absorbed in the wood to make it difficult to measure the drying conditions, middle coating and upper coating were applied in sequence to the specimens that had completed initial coating in batch for the test.

\subsection{Lacquer conditioning dryer}

To test the drying conditions, various conditions should be equally prepared and constantly maintained in the test space. However, although temperature control was available in the 'chiljang', a lacquer drying method for lacquer, moisture should be manually supplied, and it was difficult to constantly maintain humidity (Fig. 1). Also, convection did not occur in the internal space only to cause moisture congestion and resulted in uneven temperature and humidity. Therefore, a 'lacquer conditioning dryer' was designed and used in the experiment (Fig. 2). The 'lacquer conditioning dryer' consists of an air supplier (Fan) to supply humidity and warmth into the chamber, of which temperature and humidity were measured to run the pan according to the environmental changes. A perforate plate with countless holes was installed between the chamber and pan to allow fine air supply. As air supply from the pan was made to the lacquered target almost windlessly through the perforated pan, rapid moisture change was inhibited to dry lacquer in an environment with certain

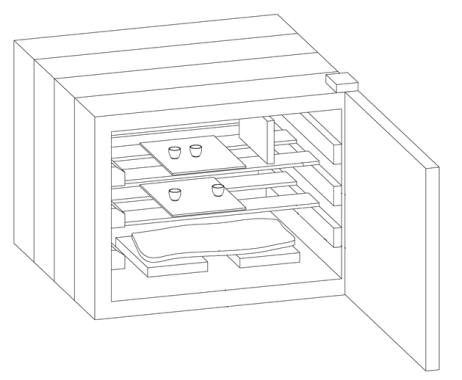

Fig. 1. Diagram of Chiljang. 


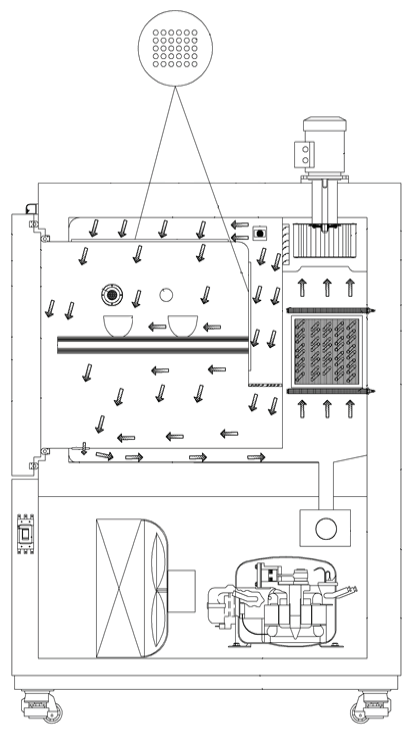

Fig. 2. Perspective diagram of humidity control machine.

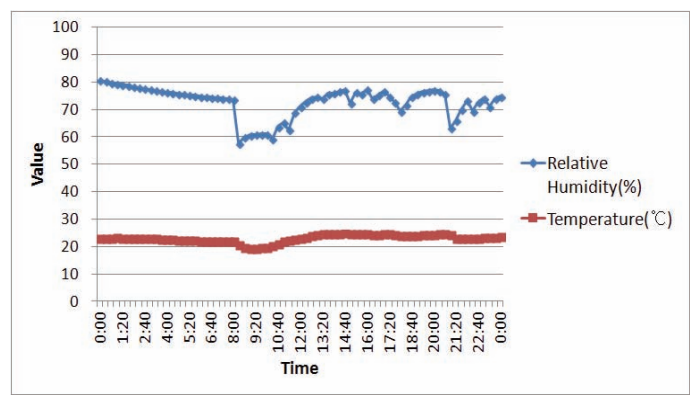

Fig. 3. Temperature-humidity changes of Chiljang.

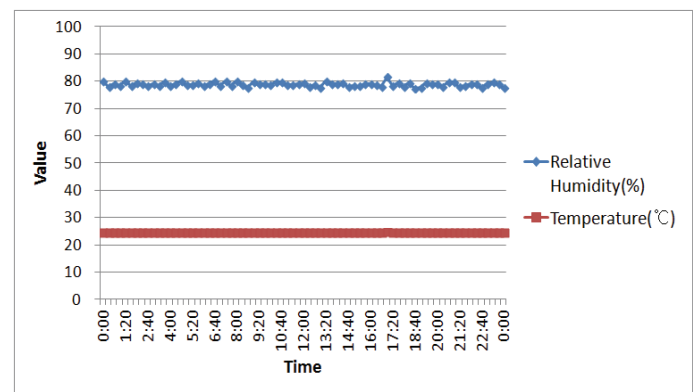

Fig. 4. Temperature-humidity changes of humidity control machine (setting $24^{\circ} \mathrm{C}$, $\mathrm{RH} 80 \%$ ). temperature and humidity.

The preliminary test confirmed that temperature and humidity were more constantly maintained than chiljang as the existing drying field (Fig. 3, Fig. 4).

\subsection{Drying condition experiment}

Temperature of the humidity control machine was set to $24 \pm 1{ }^{\circ} \mathrm{C}$, while humidity was set to $60 \%$, $70 \%$, 80\%, and $90 \%$. Three specimens were exposed to such environment in order to dry Jungchil (Middle layer) and Sangchil (Upper layer). Thus in this study, achieving up to Sangchil formed triple lacquered layer. The drying aspect was checked with the lapse of time, and the curing drying time at which the lacquer was completely dried was measured at intervals of 3 hours. The test for confirming the dryness was carried out using a drying test in accordance with KS M 5000. In KS M 5000-2511 drying condition and test method, drying hard condition indicates that there is no stretch or wrinkle of the layer and no other abnormality when it is twisted at an angle of 90 degrees while holding the arm vertically to press hard with thumb.

\subsection{Evaluation of properties}

To investigate whether two different types of lacquer with different urushiol contents exhibit different optical properties depending on the drying rate, which varies by drying condition, Jungchil and Sangchil were applied to the specimen of Korean and Chinese lacquer in the environment of relative humidity of $90 \%$ (humidity control machine) and the properties of the dried lacquer layer were evaluated. At the same time, lacquer layer was obtained by exposing three specimens to the created environment. The same procedure was repeated twice and each three specimens group was divided into $90 \%$ (A) and 90\% (B). Two drying conditions were additionally prepared for comparison and triple 
specimens were exposed and evaluated in the same way. First, properties of the specimens dried by exposure to a relative humidity of $60 \%$ in the humidity control machine for 30 days were measured. Regarding the specimens exposed to $60 \%$ of the environment for a long time, drying of Jungchil occurred at a very slow rate from the surface and thus, the application of Sangchil was difficult. Accordingly, only Jungchil was used as a target sample. Second, specimen of which Sangchil was dried at saturation humidity with relative humidity of 99\% or more after Jungchil was cured and dried at $80 \%$ relative humidity in the humid control machine.

\subsubsection{Cross section observation}

The cross section of the lacquer layer was observed through a microscope. Regarding lacquered specimens, seven sections which were cut to the same thickness of $20 \mu \mathrm{m}$ were placed on a preparat and then, preparat for layer observation was prepared. The thickness and color of the layer were confirmed through the same light amount of transmitted light at a high magnification (400 magnification) using an optical microscope (Eclipse Lv 100, Nikon, Japan).

\subsubsection{Brightness and gloss}

In this study, the brightness and gloss of the surface of each lacquer layer were measured with a spectrophotometer (A-6800, BYK, USA). Brightness is expressed as $L$ value and gloss as $G$ value. Brightness is the intensity of color, expressed as a number from 0 to 100 according to the CIE Lab color space. The higher the number, the brighter and the closer to 0 , the darker. Regarding gloss which is a measure of reflected light, resultant value is represented by a quantitative value from 0 to 100 when the incident angle of light is 60 $\circ$. Since the specimen used is a preformed wood plate, the inherent gloss of the wood may affect the surface gloss of the lacquer overlaid on top. Accordingly, the brightness and gloss of the Sangchil layer with lacquered layer which was overlaid three times through Chochil, Jungchil, and Sangchil were compared.

\section{RESULTS and DISCUSSION}

\subsection{Drying condition experiment}

The humidity control machine was used to measure the time when curing drying was completed at intervals of 3 hours. As a result of the measurement, it was found that both Korean and Chinese lacquers dried faster when the relative humidity was near $100 \%$ at $24 \pm$ $1{ }^{\circ} \mathrm{C}$. Furthermore, at $24 \pm 1{ }^{\circ} \mathrm{C}$ and less than $70 \%$ relative humidity, no drying as setting to touch occured within 336 hours (14 days) and thus, it was confirmed that it takes longer than that. The specimens simultaneously exposed to the same environment showed the same drying rate in the triple samples. As a result of illustrating the drying rate of Korean lacquer and Chinese lacquer dried at the same time in a graph, Korean lacquer was confirmed to be dried 2-3 times faster than Chinese lacquer (Fig. 5).

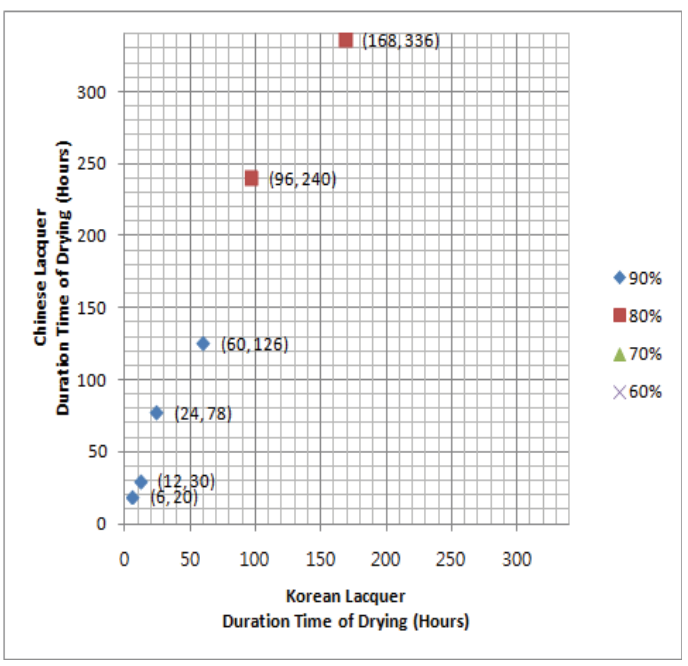

Fig. 5. Relationship between duration time of drying Korean and Chinese lacquer in each drying conditions. 


\subsection{Properties evaluation}

\subsubsection{Section observation}

The specimens dried under various drying conditions were all cut to a thickness of $20 \mu \mathrm{m}$ to prepare a section. They were observed with the same amount of transmitted light. As a result of the observation, The average height of the lacquer layer of Jungchil formed on the specimen was about $16 \mu \mathrm{m}$. In addition, the average height of the lacquer layer on Sangchil portion was about $31 \mu \mathrm{m}$. All of the specimens were found to have uniformly formed Jungchil and Sangchil over the Chochil that had penetrated into the wood substrate. As a result of comparison of Korean lacquer and Chinese lacquer dried at the same time, in case of Korean lacquer, the color is more intense than Chinese lacquer (Fig. 6). The Jungchil layer of the specimen dried over a long period of 30 days at a relative humidity of $60 \%$ showed a very light color compared to the Jungchil layer of the specimen dried at $90 \%$. Accordingly, it is judged that the drying by the oxidation polymerization reaction did not occur sufficiently (Fig. 7).

Moreover, the color difference between the Jungchil
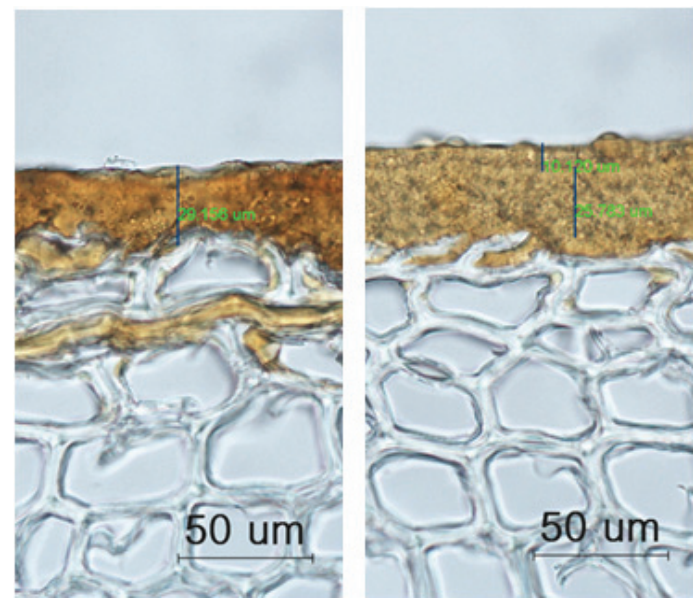

Fig. 6. triple lacquered layer drying RH 90\%(B). (left-Korean, right-Chinese).
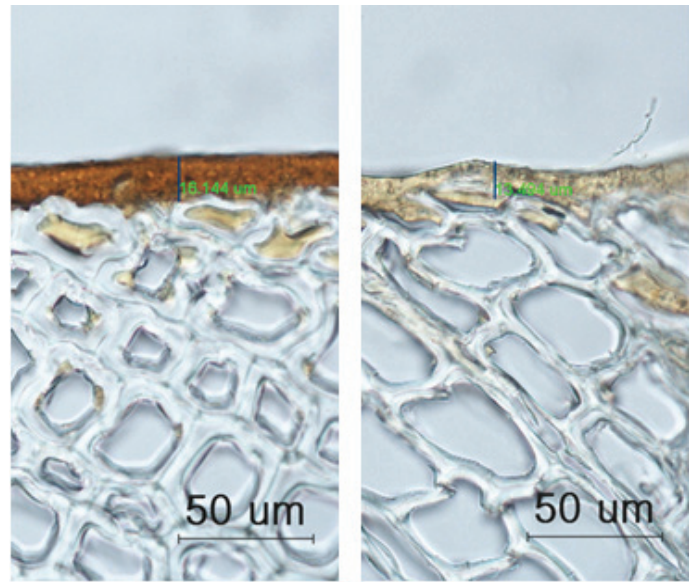

Fig. 7. Korean twice lacquered layer. (left-dried $\mathrm{RH}$ $90 \%$, right-dried $\mathrm{RH} 60 \%$ ).
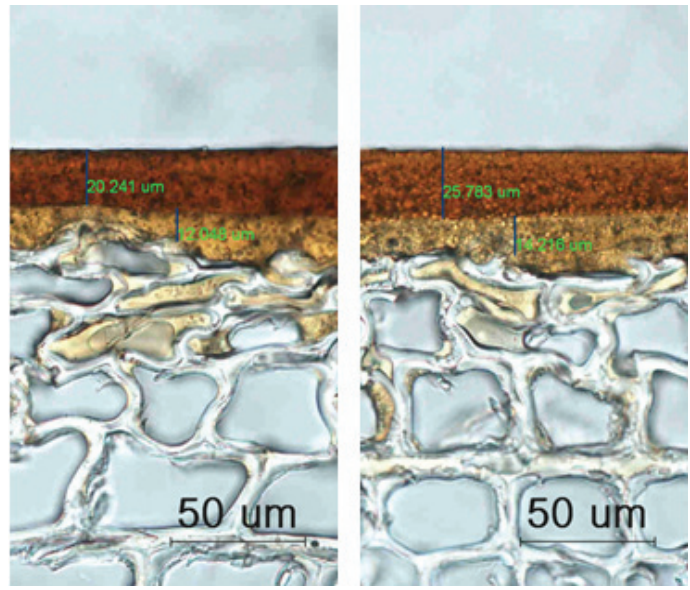

Fig. 8. triple lacquered layer RH 99\%. (left-Korean, right-Chinese).

and Sangchil layers in the Sangchil part of the specimen dried at saturated humidity was apparent. Sangchil dried at 99\% saturated humidity (less than 3 hours for Korean lacquer, and 18 hours for Chinese lacquer) showed darker color than Jungchil layer (96 hours for Korean lacquer and 240 hours for Chinese lacquer) dried at $80 \%$ (Fig. 8). It was judged that there was a difference in color of the layer depending on the drying speed. 


\subsubsection{Brightness and gloss}

The surface brightness and the gloss of the specimen layer were respectively measured, quantified and compared. For easy comparison, Sangchil layer sample's $L$ value and $G$ value, which are an intermediate value among the $L$ value of brightness and $G$ value of gloss triple specimens, are listed in the order of the fast drying time in graph below (Fig. 9, Fig. 10). Curing and drying completion time of Sangchil at relative humidity of 99\% was less than 3 hours for Korean lacquer and 18 hours for Chinese lacquer. The following were targeted: 90 (A) Sangchil of which the curing and drying time was 6 hours for Korean lacquer, 21 hours for Chinese lacquer and 90(B) Sangchil of which the curing and drying time was 60 hours, and 126 hours, respectively.

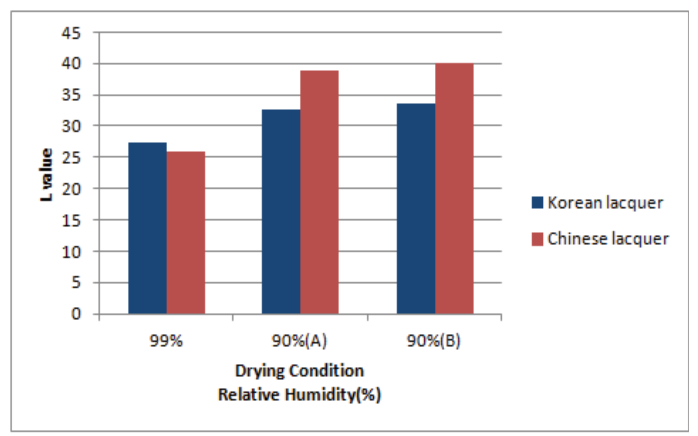

Fig. 9. Lightness of triple coated samples.

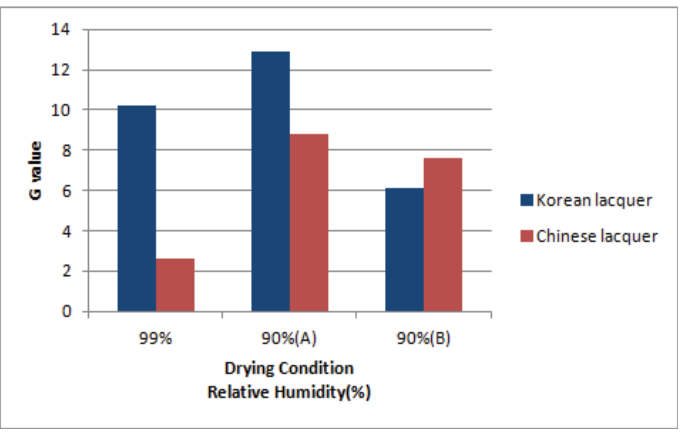

Fig. 10. Gloss of triple coated samples.
Lower L value was associated with short drying time for both Korean Sangchil layer and Chinese Sangchil layer. It was confirmed that the $\mathrm{L}$ value of domestic lacquer was lower than that of Chinese lacquer in an environment with a relative humidity of $90 \%$, Korean.

Although $\mathrm{G}$ value of $90 \%(\mathrm{~A})$ of which drying time of the Sangchil layer is faster than that of $90 \%(B)$ at relative humidity of $90 \%$ is greater than $90 \%(B), G$ value of Sangchil layer dried at saturated humidity (99\%) where drying time is the fastest was found to be low.

Thus, In both Korean lacquer and Chinese lacquer, the faster the drying time, the lower the brightness of the sample and the higher the gloss. However, it was confirmed that the lacquer dried at saturation humidity (99\%) had a lower gloss of the surface.

\section{CONCLUSION}

In this study, we designed the humidity control machine that maintains constant temperature and humidity and by using this, examined the drying conditions of lacquer with different composition ratios under different drying conditions through drying condition experiment. The optical properties of the resulting layer were evaluated to obtain a technique for forming a drying condition for obtaining a lacquer layer during preservation of desired lacquerwares.

Through this study, it was confirmed that the humidity control machine can form a constant drying environment, and maintain it stable, and be utilized for lacquer drying. The gloss and chromaticity of lacquer layer were different according to the content of urushiol and the drying rate. The conclusions are as follows.

It was found that the drying rate of Korean lacquer of which urushiol content is about $13.4 \%$ higher (excluding moisture content) was 2 to 3 times faster than Chinese lacquer and the higher the humidity, the shorter the drying time. Under the relative humidity 
A Study on the Optical Characteristics According to the Lacquer Drying Conditions for the Conservation of Lacquerwares

of $70 \%$ or less, the lacquer was not dried for 336 hours, and thus, there was a drawback that the ease of operation was poor. Long-term exposure (more than 30 days) results in drying of the surface, but it is difficult to judge that the lacquer is dried by oxidative reaction due to insufficient color change.

Further, it was found that Korean lacquer layer with high urushiol content has lower brightness than Chinese lacquer layer. In addition, it was confirmed that the faster the drying rate, the lower the brightness and the higher the gloss even though it is the same kind of lacquer. However, when it became close to saturated humidity, the lacquer was dried rapidly, and the brightness was greatly lowered, but the gloss was greatly decreased.

Therefore, drying rate can be predicted in accordance with drying conditions and major components of lacquer used when forming lacquer layer using lacquer during conservation and restoration of lacquerwares in the future, and the characteristics of the lacquer layer can be predicted depending on drying time. It is expected to be used as basic data.

\section{ACKNOWLEDGMENT}

This research was supported by 2016 Academic Research Support Project funded by Korea National University of Cultural Heritage(NUCH).

\section{REFERENCES}

Anzai, K., Lu, R., Phuc, B.T., Miyakoshi, T. 2014. Development and Characterization of Laccol Lacquer Blended with Urushiol Lacquer, International Journal of Polymer Analysis and Characterization 19(2): 130-140.

Cho, S.M., 2000. Study of Characteristic Properties on
Lacquer and its Film Processing, Master, Thesis, Yonsei University, Korea.

Choi, J.W., Kim, S.C. 2018. Analysis of Lacquer and CNSL Using Infrared Spectrometer and PyrolysisGC/MS, Journal of the Korean Wood Science and Technology 46(1): 1-9.

Jang, E.J. 2016. Study on Physical Properities of Mixed Filler for Conservation of Lacquer Wares, Master, Thesis, Korea National University of Cultural Heritage, Korea.

Kenjo, T. 1986. Effective Pretreatments for the Identification of Ancient Urushi Films, Science for conservation (25): 49-54.

Kim, H.J., Lee, B.H. 2002. Development Trends of Natural Coatings - Rhus lacquer, Dendropanax lacquer and Cashew Nutshell Liquid(CNSL) lacquer, Journal of the Korean Industrial and Engineering Chemistry 5(5): 35-43.

Kim, S.C. 2007. Analysis and Conservation of Lacquer Wares from Archaeological Sites in Korea, Ph.D, Thesis, Chungbuk National University, Korea.

Kim, Y.J., Park, W.K. 2005. Tree-Ring Dating of Korean Furniture and Woodcraft Works of the Late Joseon Period and the Modem Era: A Case Study, Korean Journal of Art History (246): 247-274.

Son, D.H. 2006. Traditional Craft of Lacquer, Korea Cultural Heritage Foundation, Seoul, Korea.

Song, H.G., Han, C.H. 2001. Study on Refining Technique of Raw Lacquer(1)-Properties of Raw Lacquer,Refined Lacquer and Film according as Their Collecting Places and Seasons-, Journal of the Korean Wood Science and Technology 29(1): 31-42.

Toshiko, K., Kenjo, T. 1970. Relationship between hardening of Japanese lacquer urushi and humidity, Science for conservation (6): 43-44. 


\title{
APPENDIX
}

\author{
(Korean Version)
}

\section{칠기문화재 보존을 위한 옻칠 건조조건에 따른 광학적 특성 연구}

요약 : 칠기문화재의 보존처리는 문화재 보존·복원의 기본 원칙에 따라 전통재료를 활용하여 보존처리하는 것을 기본으로 하므로 보존처리 재료로써 옻칠의 사용이 요구된다. 하지만 옻칠은 고습의 환경에서 건조가 이루어져 수분에 의한 기물의 손상 가능성을 주의해야 한다. 또한 천연물질이므로 종류 및 산지에 따라 성분 조성이 달라져 이에 따른 건조특성과 건조조건이 다르게 나타나는 특징이 있어 균일한 결과를 내기 어렵다. 본 연구에서는 옻칠 조습 건조기를 이용하여 성분 함량에 따른 옻칠의 건조조건을 파악하고 결과로 얻어지는 옻칠 도막의 광학적 특성을 분석하여 데이터베이스화 하고자 하였다. 동일한 환경에 두 종류의 옻칠을 노출한 결과, 수분을 제외한 주성분비에서 우루시올의 비율이 평균 $13.4 \%$ 높은 국내산 옻칠이 낮은 중국산 옻칠보다 건조속도가 2 배 3 배 빠름을 알 수 있었고 두 옻칠 모두 습도가 높은 환경일수록 건조시간이 단축됨을 확인하였다. 그리고 건조시간이 짧을수록 명도가 낮고 광택이 강한 옻칠 도막이 형성되었다. 단, 포화습도에서는 광택이 떨어지 는 것을 확인하였다. 상대습도 $70 \%$ 이하에서는 옻칠의 건조가 원활히 이뤄지지 않았고 장기간 건조되더라고 도막의 명도가 높고 색도 차이가 낮아 견고한 옻칠 도막을 형성하였다고 보기 어렵다.

\section{1. 서 론}

칠기문화재는 칠기문화재의 보존처리는 문화재 보존복원의 기본 원칙에 따라 원재료인 전통재료를 활용하여 보존처리하는 것을 기본으로 한다. 따라서 구조적 특성과 손상 형태에 따라 복원재료를 결정하고, 고증을 통한 결손 부위의 보수·복원이 진행되고 있다(Jang, 2016). 칠기문화재의 보존처리시 복원재료로써 옻칠의 사용이 요구되지만 옻칠을 건조시키는 조건이 매우 까다로워 칠기문화재의 보존처리에 적용하는 데 어려움이 있다. 옻칠의 최적 경화조건은 상온의 고습환경으로 알려져 있다. Toishi, K.와 Kenjo, T.(1970)는 80-85\%의 습도와 20-30 ${ }^{\circ} \mathrm{C}$ 의 온도에서 건조가 이뤄진다고 하였으며, Son, D.H.(2006)은 상대습도 $60-80 \%$, 온도 $20-28^{\circ} \mathrm{C}$ 를 옻칠의 경화조건으로 제시하였다.

옻칠은 경화조건에서 2단계로 반응이 진행되며 경화 건조한다. 경화 초반에 옻칠에 포함된 산화효소인 락카아제가 수증기에 서 촉매 작용하여 우루시올이 산화하면, 중합반응이 일어나면서 옻칠의 건조가 이뤄지고 이후 지속적으로 우루시올과 산소의 자동산화반응에 의해 옻칠의 도막이 형성된다(Kenjo, 1986; Kim and Lee, 2002). 이러한 경화과정은 산소가 필수적이며 우루시 올 기능기가 큰 역할을 한다(Choi and Kim, 2018).

경화조건과 경화 메커니즘이 연구되었음에도 칠기문화재 보존처리에는 적용하기 까다로운 실정이다. 우선 사용하는 옻칠의 산지, 채취 시기 등에 따라 주요 성분 함유량이 달라지며, 건조특성과 건조조건이 다르게 나타나 균일한 결과를 내기 어렵다는 점이다. 또한 기존의 장인들이 사용하는 옻칠 건조장(칠장)은 균일한 온·습도 유지가 어려워 정확한 도막의 특성을 예측하기 어렵다. 따라서 보존처리시에는 사용하는 옻칠의 특성을 알고, 얻고자 하는 옻칠 도막의 특성에 맞춰 건조조건 설정이 이뤄져야 할 필요가 있다. 하지만 옻칠의 성분 조성과 건조조건에 따른 옻칠 도막의 다양한 특성에 관한 구체적인 연구는 미비한 실정이다. 따라서 본 연구에서는 항온항습이 가능한 ‘옻칠 조습 건조기'를 고안하고 이에 주로 사용되는 두 종류의 옻칠을 건조조건별로 노출하여 주요 성분 함유량의 차이에 따른 건조속도 차이와 그에 따른 도막의 광학적 특성을 분석하여 옻칠 도막의 결과 예측이 가능하도록 하고자 한다. 천연재료의 특성상 다양한 성분비의 옻칠 그대로를 적절하게 다루는 방법을 제공하고자 한다.

\section{2. 재료 및 방법}

\section{1. 목재}

예로부터 우리나라 전통가구의 재료로는 소나무, 전나무, 먹감나무, 단풍나무 등이 쓰였으며, 그중 소나무가 가장 흔하게 사용된 것으로 조사되고 있다(Kim과 Park, 2005). 따라서 본 실험에서 국내산 소나무(Pinus spp.)를 선정하여 목재 시험편으로 제작하였다. 시험편은 가로 $7 \mathrm{~cm}$, 세로 $22 \mathrm{~cm}$, 두께 $0.7 \mathrm{~cm}$ 의 크기로 절단하고 $13 \%$ 이하의 함수율로 건조하였다. 그리고 단면을 연마하여 면을 고르게 하였다. 
A Study on the Optical Characteristics According to the Lacquer Drying Conditions for the Conservation of Lacquerwares

\section{2. 옻칠}

천연 옻칠은 경우에 따라 다소 차이는 있지만 페놀성 유도체인 카테콜(60-65\%), 수분(20-25\%), 고무질을 구성하는 다당류 (5 7\%), 함질소 물질을 구성하는 당단백질(2 5\%) 그리고 산화효소인 라카아제(1\%) 등의 혼합물로 에멀션 상태이다(Cho, 2000; Kim, 2007). 카테콜의 종류는 수종과 기후에 따라 다르며 동북아시아에서 자생하는 참옻나무 옻칠의 카테콜은 우루시올이 다(Anzai, Lu, Phuc, Miyakoshi, 2014). 또한 같은 지역에서 채취되는 옻칠이더라도 산지와 채취 시기에 따라서 각각 다른 구성비를 이루고 있다.

따라서 주요 성분비 차이가 있는 두 가지의 칠을 비교 연구하기 위해 보존처리에 쓰이는 두 종류의 옻칠을 선정하고 불순물만 을 제거하여 여과한 생칠로 사용하였다. 강원도 원주시에서 채취한 국내산 옻칠과 중국산 옻칠을 사용하여 시편을 제작하였다. 두 옻칠의 여과한 생칠을 가열하여 수분을 제거하고, 아세톤을 첨가한 후 교반하여 우루시올을 분리하는 방법으로 함량비를 분석하였다(Song and Han, 2001). 두 옻칠에서 수분과 우루시올을 각각 분리하여 그 함량을 2회에 걸쳐 측정한 결과, 수분을 제거한 후 국내산 옻칠이 중국산 옻칠보다 우루시올의 함량이 평균 $13.4 \%$ 높음을 확인하였다(Table. 1).

\section{3. 시험편 제작}

본 실험은 목심칠기의 제작과정에 따라 초칠을 한 후 중칠과 상칠을 하여 진행하였다. 이때, 미세 투과망을 이용하여 불순물을 거른 것 외에 다른 정제과정을 거치지 않은 옻칠을 사용하였다. 초칠은 소지 목재(목재 시험편)에 묽은 옻칠을 하는 것으로 가장 먼저 목재에 흡수되어 백골의 수분 흡수를 방지하고 다음 칠의 과정에서 접착을 강화시키기 위한 것이다. 그리고 초칠보다 높은 농도의 묽은 칠을 하는 중칠과 상칠은 옻칠 도막을 형성하며 도막의 특성을 결정한다.

하나의 시험편에서 표면의 절반은 중국산 옻칠을, 나머지 절반은 국내산 옻칠을 적용하였다. 사전 실험을 통해 초칠의 농도는 옻칠과 테라핀유(희석제)의 비율이 $1: 2$, 중칠과 상칠은 $1: 1$ 인 시험편이 건조속도와 도막의 형성을 관찰하기에 가장 적합함을 확인하였다. 초칠의 경우 목재에 흡수되면서 건조조건 측정이 어려워 각각의 재료로 초칠을 일괄적으로 마친 시험편에 중칠과 상칠을 단계적으로 적용하여 실험을 진행하였다.

\section{4. 옻칠 조습 건조기}

건조조건 실험을 위해서는 실험 공간 내 다양한 조건의 환경이 균일하게 조성되어야 하며 지속적인 유지가 필요하다. 하지만 기존의 옻칠을 건조하는 방안인 ‘칠장'은 목제 프레임 내부 열선을 통해 온도제어는 가능하지만 수분을 수동으로 공급해야 하여 습도의 지속적인 유지가 어렵다(Fig. 1). 또한 내부 공간에서 대류현상이 일어나지 않아 수분이 정체하여 온·습도가 고르지 못하다는 단점이 있어 '옻칠 조습 건조기'를 고안하여 실험에 사용하였다(Fig. 2). '옻칠 조습 건조기'는 챔버 내부로 습기와 온기를 공급할 수 있도록 수분을 포함한 공기공급수단(팬)을 구성하고 챔버에는 온습도를 측정하여 환경 변화에 따라 팬을 가동하도록 하였다. 챔버와 팬의 사이에는 공기의 공급이 미세하게 이루어지도록 소공이 무수한 천공판을 설치하였다. 팬을 통해 공급되는 공기가 천공판을 통해 옻칠한 대상물까지 무풍에 가깝게 공급될 수 있도록 함으로써 급격한 수분 변화를 줄이도록 하여 설정한 온·습도가 균일하게 형성되는 환경에서 옻칠을 건조시키는데 그 목적을 두었다.

사전 실험을 통해 기존의 건조장인 칠장에 비해 설정 온·습도가 안정하게 유지되는 것을 확인하였다(Fig. 3, Fig. 4).

\section{5. 건조조건 실험}

옻칠 조습 건조기에서 온도 $24 \pm 1{ }^{\circ} \mathrm{C}$, 습도 $60 \%, 70 \%, 80 \%, 90 \%$ 의 환경을 각각 조성하고 3 배수의 시험편을 각각 중칠과 상칠을 건조하기 위하여 노출하였다. 시간의 경과에 따라 건조양상을 확인하여 옻칠이 완전히 건조되는 경화 건조 시간을 3 시간 간격으로 측정하였다. 건조여부를 확인하는 시험법은 KS M 5000을 따라 경화 건조 시험을 사용하였다. KS M 5000-2511 건조 상태 및 시험의 방법에서 경화 건조는 도막면에 팔을 수직으로하여 힘껏 엄지손가락으로 누르면서 90 도 각도로 비틀어 볼 때 도막이 늘어나거나 주름이 생기지 않고 다른 이상이 없는 상태임을 나타낸다.

\section{6. 광학적 특성 평가}

우루시올의 함량의 차이가 있는 다른 두 종류의 옻칠이 건조조건에서 다르게 나타내는 건조 속도에 따라 다른 광학적 특성을 나타내는지 알아보고자 상대습도 $90 \%$ (조습건조기) 환경에서 시험편에 국내산 및 중국산 옻칠을 중칠과 상칠하여 건조한 옻칠 도막의 광학적 특성을 각각 평가하였다. 동시에 3 배수 시험편을 조성한 환경에 노출하여 옻칠 도막을 얻었다. 동일과정을 2 회 반복하여 각각의 3 배수 시험편 그룹을 $90 \%(\mathrm{~A})$ 와 $90 \%(\mathrm{~B})$ 으로 나누어 표기하였다. 비교를 위해 2가지의 건조조건을 추가적 
으로 조성하여 3 배수의 시험편을 노출하고 이를 동일한 방법으로 평가하였다. 첫 번째는 조습건조기 내 상대습도 $60 \%$ 에 30 일간 장시간 노출시켜 건조시킨 시험편의 광학적 특성 평가를 실시하였다. $60 \%$ 환경에 장시간 노출시킨 시험편은 중칠의 건조가 표면에서부터 매우 느린 속도로 이뤄지는 까닭에 상칠의 적용이 어려워 중칠만을 대상 시료로 하였다. 두 번째로는 조습건조기 내 상대습도 $80 \%$ 에서 중칠을 경화 건조시킨 후 상대습도 $99 \%$ 이상인 포화습도에서 상칠을 건조시킨 시험편을 제작하였다.

\subsection{1. 단면 관찰}

현미경 관찰을 통해 옻칠 도막의 단면을 관찰하였다. 옻칠된 시험편에서 $20 \mu \mathrm{m}$ 두께로 동일하게 절삭한 칠편을 프레파라트 위에 올린 후 도막 관찰용 프레파라트를 제작하였다. 이를 광학현미경(Eclipse Lv 100, Nikon, Japan)을 사용하여 고배율(400배) 로 동일한 광량의 투과광을 통해 도막의 두께 및 색상을 확인하였다.

\subsection{2. 명도 및 광택도 측정}

본 연구에서는 분광색도계(A-6800, BYK, USA)로 시험편에서 각각의 옻칠 도막 표면의 명도와 광택도를 측정하였고 명도는 $\mathrm{L}$ 값, 광택도는 G 값으로 나타난다. 명도는 색상의 명암을 나타내는 것으로 CIE Lab 색공간에 따라 0 부터 100 까지의 수치로 나타내었다. 수치가 높을수록 밝고 0 에 가까울 수록 어둡다. 광택도는 반사광을 측정하는 것으로 광의 입사각이 $60^{\circ}$ 일 때를 채용하여 결과 값을 0 부터 100 까지의 양적 수치로 나타내었다. 사용한 시험편은 초칠한 목판재이므로 시험편마다 목재 고유의 광택도가 위로 중첩되는 옻칠의 표면 광택도에 영향을 미칠 수 있다. 따라서 초칠, 중칠, 상칠을 거쳐 옻칠 도막이 3회 중첩된 상칠 도막의 명도와 광택도를 비교하였다.

\section{3. 결과 및 고찰}

\section{1. 건조조건 실험}

조습건조기에서 3 시간 간격으로 경화 건조가 완료된 시점을 측정한 결과, 국내산과 중국산 옻칠 모두 $24 \pm 1^{\circ} \mathrm{C}$ 에서 상대습도가 $100 \%$ 에 가까울수록 건조가 빠르게 되는 것으로 나타났다. 그리고 $24 \pm 1^{\circ} \mathrm{C}$, 상대습도 $70 \%$ 이하에서는 336 시간(14일) 내에 지촉 건조가 일어나지 않아 그 이상의 기간이 소요되는 것으로 확인하였다. 동일한 환경에 3 배수로 동시 노출한 시험편은 3 배수 시료에서 건조 속도가 동일하게 나타났다. 동시에 건조시킨 국내산과 중국산 옻칠의 건조속도를 그래프로 나타낸 결과, 국내산 옻칠이 중국산 옻칠보다 2 3배 빠르게 건조되는 것으로 확인되었다(Fig. 5).

\section{2. 특성 평가}

\subsection{1. 단면 관찰}

여러 건조조건에서 건조된 시험편을 모두 20^m로 두께를 동일하게 절삭하여 박편을 제작하고 이를 동일한 광량의 투과광으로 관찰한 결과, 시험편에 형성된 중칠 부분의 옻칠 도막은 평균 높이가 약 $16 \mu \mathrm{m}$ 으로 나타났다. 그리고 상칠 부분의 옻칠 도막 평균 높이는 약 31 $\mu$ 로 관찰되었다. 시험편 모두 목재 소지에 침투된 초칠 위로 중칠과 상칠이 고르게 형성된 것을 확인하였다. 동시에 건조한 국내산 옻칠과 중국산 옻칠을 비교한 결과, 국내산 옻칠의 경우 중국산 옻칠보다 색이 더 짙게 관찰된다(Fig. 6). 상대습도 $60 \%$ 에서 30 일의 장기간에 걸쳐 건조시킨 시험편의 중칠 도막은 $90 \%$ 에서 건조시킨 시험편의 중칠 도막에 비해 매우 옅은 색으로 나타나 산화중합반응에 의한 건조가 충분히 일어나지 않은 것으로 판단된다(Fig. 7).

또한 포화습도에서 건조한 시험편의 상칠 부분에서 중칠과 상칠 도막의 색상차가 뚜렷이 나타났다. $99 \%$ 의 포화습도에서 상칠을 건조한 시험편은 상칠 도막(국내산 3 시간 미만, 중국산 18 시간)이 $80 \%$ 에서 건조시킨 중칠 도막(국내산 96 시간, 중국산 240시간)보다 짙은 색상을 나타냈다(Fig. 8). 이는 건조속도에 따라 도막의 색상의 차이가 있는 것으로 판단된다.

\subsection{2. 명도 및 광택도 측정}

시험편 도막의 표면 명도와 광택도를 각각 측정하고 이를 수치화하여 비교하였다. 아래 그래프에서는 비교가 용이하도록 3 배수 시험편 시료의 명도인 L값과 광택도인 $\mathrm{G}$ 값 중 각각 중간값을 가지는 상칠 도막 시료의 $\mathrm{L}$ 값과 $\mathrm{G}$ 값을 건조시간이 빠른 순서대로 그래프에 나열하였다(Fig. 9, Fig. 10). 상대습도 $99 \%$ 상칠 시험편의 경화 건조 완료 시점은 국내산 옻칠은 3시간 미만, 중국산 옻칠은 18 시간이었으며, 90(A) 상칠의 경화 건조 시간은 국내산 옻칠 6 시간, 중국산 옻칠 21시간, $90(\mathrm{~B})$ 상칠은 각각 60 시간, 126 시간으로 나타난 것을 대상으로 하였다. 
$\mathrm{L}$ 값은 국내산 상칠 도막과 중국산 상칠 도막 모두 건조시간이 빠를수록 낮게 나타났다. 상대습도 $90 \%$ 의 환경에서는 국내산 옻칠이 중국산 옻칠보다 $\mathrm{L}$ 값이 낮게 나타나는 것을 확인하였다.

$\mathrm{G}$ 값은 상대습도 $90 \%$ 에서 상칠 도막의 건조시간이 빠른 $90 \%(\mathrm{~A})$ 가 느린 $90 \%(\mathrm{~B})$ 보다 높으나 건조시간이 가장 빠른 포화습도 (99\%)에서 건조한 상칠 도막의 $\mathrm{G}$ 값은 낮게 나타났다.

따라서 국내산 옻칠과 중국산 옻칠 모두 건조시간이 빠를수록 시료의 명도가 낮아지고 광택도가 높아지나 포화습도(99\%)에 서 건조한 옻칠은 오히려 표면의 광택도가 떨어지는 것을 확인하였다.

\section{4. 결 론}

본 연구에서는 안정적으로 일정한 온·습도를 유지하는 옻칠 조습 건조기를 고안하여 이를 이용해 주요 성분비의 차이를 가지는 옻칠이 어떠한 건조조건에서 건조가 이루어지는지 건조조건 실험을 통해 연구하고자 하였다. 그리고 얻어지는 도막의 광학적 특성을 평가하여 원하는 칠기문화재의 보존처리시 옻칠 도막을 얻기 위한 건조조건을 형성하는 기술을 얻고자 하였다.

본 연구를 통해 옻칠 조습 건조기를 이용하여 일정한 건조환경을 형성하고 이를 안정적으로 유지하며 옻칠 건조에 활용할 수 있음을 확인하였다. 그리고 우루시올의 함량과 건조 속도에 따라 옻칠 도막의 광택도 및 색도가 다르게 나타남을 확인하였으 며 결론은 다음과 같다.

우루시올 함량이 약 $13.4 \%$ 높은(수분 함유량 제외) 국내산 옻칠이 중국산 옻칠에 비해 건조속도가 2 배 3배 빠름을 알 수 있었으며 습도가 높을수록 건조시간이 단축됨을 확인하였다. 상대습도 $70 \%$ 이하에서는 옻칠의 건조가 336시간동안 이뤄지지 않아 작업의 용이성이 떨어지는 단점이 있었으며, 장기간(30일 이상) 노출시키면 표면의 건조는 일어나나 색변화가 미비하여 산화효소반응을 통한 옻칠 건조가 이뤄진 것으로 판단하기 어렵다.

또한 우루시올 함량이 높은 국내산 옻칠의 도막이 중국산 옻칠 도막보다 명도가 낮은 도막을 형성하는 것으로 나타났다. 그리고 동일한 종류의 옻칠이더라도 건조 속도가 빠른 도막일수록 명도가 낮아지고 광택도가 증가함을 확인하였다. 다만 포화습 도에 가까워지게 되면 옻칠이 급격히 건조되어 명도가 크게 낮아지는 반면 광택도는 크게 떨어지는 것을 확인하였다.

따라서 향후 칠기문화재의 보존 및 복원시 옻칠을 이용하여 옻칠 도막을 형성하고자 할 때 사용하는 옻칠의 주요 성분비에 따라 건조조건에 따른 속도를 예측하고 건조 시간에 따라 옻칠 도막의 특성을 예측가능 하게 하는데 기초자료로써 활용될 것으로 기대된다. 